\title{
ASSOCIATION OF NATURAL FORMALDEHYDE LEVEL WITH QUALITY ATTRIBUTES OF SELECTED SEA FISH, COLLECTED FROM SOUTHEAST COAST OF BANGLADESH
}

\author{
Hossain M.A.*, Haque M.M, Zim A.F.M.I.U, Aziz M.A, Sharmin K.N. \\ Department of Applied Food Science and Nutrition \\ Chattogram Veterinary and Animal Sciences University \\ Chattogram, Bangladesh. \\ * Corresponding author: Md. Altaf Hossain, Email: altaf@cvasu.ac.bd ; Mobile: +8801728417530 \\ DOI: $10.31364 / S C I R J / v 8 . i 4.2020 . P 0420757$ \\ http://dx.doi.org/10.31364/SCIRJ/v8.i4.2020.P0420757
}

\begin{abstract}
Fishes are a rich source of proteins, vitamins, minerals as well as essential fatty acids but highly perishable because of their high water activity, neutral $\mathrm{pH}$, and presence of autolytic enzymes in their muscles. Recent time in Bangladesh fish vendors is fined by law-enforcement authorities due to the presence of formaldehyde though they don't add additional formalin in their fishes. On the other hand, some fishmongers use chemicals i.e., formalin to extend the longer shelf-life without considering public health issues, at the same time some extent of formaldehyde also produce naturally in fish muscle during the postharvest period. This study aimed to determine the natural formaldehyde level and quality attributes of six sea fish at different time interims. Results revealed that formaldehyde levels were initially raised significantly and then declined in fish muscles with elapsing of time. This study also clarified that fish muscle that produced a higher amount of natural formaldehyde possessed a longer shelf life while lower the microbial load and $\mathrm{pH}$. So it can be concluded that without using external formalin, fish vendors can preserve their fishes on around six to eight hours.
\end{abstract}

Keywords: Formaldehyde, Sea fish, Shelf life, pH, Microbial load.

\section{INTRODUCTION}

Fish is a popular food item all over the world as it has high nutritional value and easy to digest. Most people like saltwater fish rather than sweet water because of its high vitamin and mineral content [1]. Moreover, sea fish contain a more prominent amount of brain developing nutrients such as omega-3, 6, 9 fatty acids, iodine, and selenium and these nutrients also improve health conditions especially decrease the cardiac-related complications [2,3]. Bangladesh is a riverine country and has about $580 \mathrm{~km}$ coastline, that's why it produces a huge amount of fish every year where about $60 \%$ of total animal protein comes from fish. According to the FAO report, Bangladesh is now 3rd in position for inland open water capture production and 5th in world aquaculture production [4]. Among the sea fish, only Hilsha has the most distinguished contribution (around $12 \%$ ) to the country's entire fish production. The fish sector provides about 3.57\% to the national GDP in 2017-18, which also provides more than $11 \%$ of the total population of Bangladesh those are involved in this sector in full time and part-time basis for their livelihoods. Additionally, this sector also has a high potential for the prospect of the economic advancement of the country [5].

But recent times, some fishmongers have unethically added some adulterant to the fish for longer shelf-life as well as the freshness of fish. Formalin which is a solution of 37- $40 \%$ formaldehyde very common preservative use in fish for toughening the muscles along with to preserve a long time while it supposes a carcinogen [6]. For this presence of formaldehyde, most of the retailers are penalized by law enforcement authority regularly though fish muscles produced some extent of formaldehyde naturally. The quantity of formaldehyde generated in muscles depends on the muscle types, storage temperature, catching time, and feed qualities [7,8]. Enzymatic degradation of trimethylamine-oxide (TMAO) plays a great role in the production of natural formaldehyde in sea fish muscles during postharvest storage $[9,10]$. The natural formaldehyde produced in muscle is small in an 
amount that does not harm health but the higher amount may cause serious problems such as pain, vomiting, coma, and possible death [11].

Detection of formaldehyde level in fish is done by using a Formaldehyde detection machine or kit which just detects the presence or absence but not determine the actual level of it. Furthermore, these methods may have interfered with the presence of other aldehydes, ketones, or alcohol in the air. Most of the previous studies reported the level of total formaldehyde at a single time during post-harvest but not determined the natural formaldehyde level in fish muscles with elapsing of time. So there is no clear evidence of how much natural formaldehyde produced in fish muscle and how it's associated with quality of fish with time passing. Regarding these situations, the concentration of naturally occurring formaldehyde in common sea fish needs to be investigated that will give a clear message to the law-enforcement authority as well as fish vendors to preserve their fish without adding extra formalin. This study could rule out the confusion on the added amount of formalin used and natural formalin levels in fish muscles. Hence, this research aimed to determine the natural formalin level in sea fish with time changing and its association with shelf-life in the samples.

\section{METHODOLOGY}

\subsection{Fish samples collection}

Locally available fresh fish samples were collected directly from the fisherman before they were stored to supply to the local market from the southeast coastal area Cox's Bazar, Bangladesh. Among the most abundant fish species found in the southeast coastal area of Bangladesh namely Bombay duck (Harpadonnehereus), Seabass (Latescalcarifur), Silver pomfret (Pampuschinensis), Hilsha (Tenualosailisha), Silver jewfish (Pamapama) and Tuna (Euthynnusaffinis) were selected for this study. The fishes were frozen immediately in an icebox and transported to the laboratory in an insulated box. The natural formaldehyde level, pH, microbial qualities, and shelf-life of fish were analyzed in the laboratory of Applied Food Science and Nutrition and Poultry Research and Training Center (PRTC), Chattogram Veterinary and Animal Sciences University, Chattogram, Bangladesh.

\subsection{Formaldehyde Determination}

\subsubsection{Sample preparation}

Frozen fishes were thawed at ambient temperature and then filleted, minced, and homogenized. From that minced fish sample, precisely $10 \mathrm{~g}$ was blended with $200 \mathrm{ml}$ of deionized water and $10 \mathrm{ml}$ of $10 \%$ phosphoric acid for digestion of fish muscles. After that, $4 \mathrm{ml}$ of supernatant was taken and mixed with $1 \mathrm{ml}$ of $0.4 \% 2,4 \mathrm{DNPH}$, and 50ml perchloric acid solution. It was then vigorously stirred with dichloromethane followed by heating to volatilize dichloromethane, and then $1 \mathrm{ml}$ methanol added to the mixer. The mixer was then mingled and filtered with $.045 \mu \mathrm{m}$ filter before injection in sample injector [12].

\subsubsection{Standard curve establishment}

The standard formaldehyde solution was prepared as per $0.005,0.01,0.015,0.02,0.05 \mathrm{mg} / \mathrm{L}$ concentration. Then the standard solutions were run by UHPLC to get the corresponding peak area. Finally, the calibration curve was established by plotting the peak area against concentration in the Microsoft Excel sheet (Fig.1).

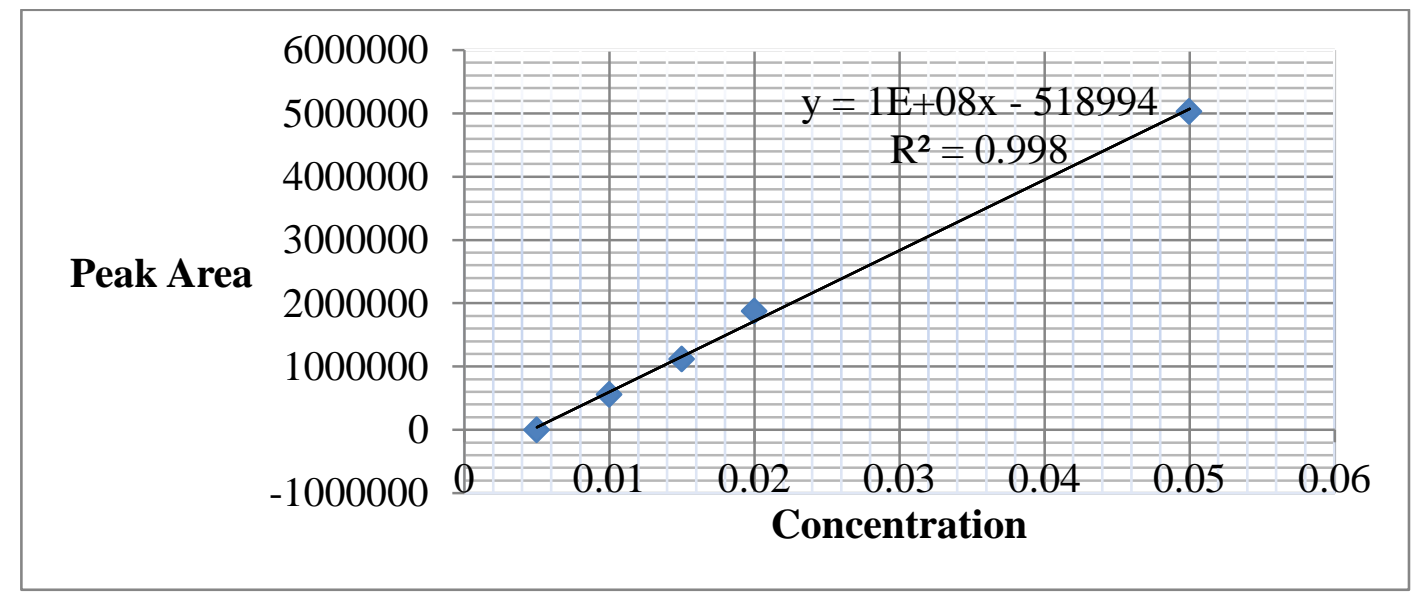

Figure 1: Standard curve for formaldehyde concentration

\subsubsection{UHPLC analysis}


Agilent 1100 (Agilent Technologies, USA) series machine was used to determine the formaldehyde in the fish sample. The C18 column, D2 lamp, UV-detector, auto-sampler temperature at $20^{\circ} \mathrm{C}$, oven temperature at $30^{\circ} \mathrm{C}$, sample volume at $15 \mu 1$, and detector at $365 \mathrm{~nm}$ were set respectively before running the samples. The Mobile phase was the mixture of Acetonitrile $70 \%$ and deionized water $30 \%$ with a flow rate of 0.5 [12].

\section{3. $\mathrm{pH}$ determination}

The glass electrode $\mathrm{pH}$ meter's sensor was washed thoroughly with deionized water and standardized by the standard buffer solution at 7.00 and 3.00. A 5 gram of fish flesh was weighed and blended with $50 \mathrm{ml}$ deionized water for 5 minutes. After that, the supernatant was separated and the $\mathrm{pH}$ was recorded by $\mathrm{pH}$ meter.

\subsection{Determination of shelf-life}

The shelf-life of fish samples were determined by a sensory panel who were experts on the freshness of fish. Overall quality was recorded on a hedonic scale of 0-10. The mean panel score for the sample was evaluated from the scores of different attributes. A score of 5 is taken as a borderline of acceptability and below was taken as rejection [13].

\subsection{Microbiological quality assessment}

The pour plate method was used to determine the microbial load of fish muscles. The total plate count was delimited by standard plate count methods. About $5 \mathrm{~g}$ of fish flesh was blended with $20 \mathrm{ml}$ of $0.2 \%$ peptone water for 15 minutes and then $0.1 \mathrm{ml}$ aliquot was spread onto plate count agar. After that, it is incubated at $37{ }^{\circ} \mathrm{C}$ for 48 hours and then the colony was counts expressed as colony-forming units per gram of muscle (CFU/g) [14]

\subsection{Statistical Analysis}

A descriptive analysis of samples was computed first. One -way ANOVA was performed to understand the significant difference between fish samples. All analysis was done by using the software SPSS version 17.0 (SPSS Inc., USA). The level of significance was set at $\leq 0.05$.

\section{RESULTS AND DISCUSSION}

\subsection{Natural formaldehyde level in sea fish}

The significant amount of natural formaldehyde was quantified in selected fresh sea fish samples. Figure 2 shows that initially, the level of naturally producing formaldehyde rose gradually in all fish samples concerning the time at a certain period and then declined with time passing. The results revealed that initial formaldehyde was lowest in Tuna and highest in Bombay duck of about 1.5 and $8.5 \mathrm{mg} / \mathrm{kg}$ sequentially besides Hilsha possessed second highest of concentration $(7.5 \mathrm{mg} / \mathrm{kg})$ and rest of the species were below $5 \mathrm{mg} / \mathrm{kg}$. A study conducted by Uddin et al. reported that the concentration of naturally occurring formaldehyde increases slowly in the fresh fish sample to time which is similar to this study [15]. The amount of formaldehyde produced in muscles indicates the freshness and quality of fish which depends on some factors such as species, time and temperature of storage, seasons of catching, etc [16].

The formaldehyde concentration in all specimens has risen until 10 hours except the Sea bass which value was increased to about 5 hours and then decreased with elapsing of time. The highest concentration was found in Hilsha muscle $(20.1 \mathrm{mg} / \mathrm{kg}) \mathrm{after} 10$ hours, similarly, Bombay duck and Silver pomfret contained a higher amount of formaldehyde of about 18.9 and $18.1 \mathrm{mg} / \mathrm{kg}$ respectively. On contrast, Sea bass, Tuna, and Silver jewfish carried about 10.1, 12.8, and $11.2 \mathrm{mg} / \mathrm{kg}$ apiece. This may be due to the presence of trimethylamine oxide (TMAO) amount in the muscle of fish which breaks down and produced equal molar of formaldehyde. The amount increases in marine fishes during frozen storage and extends the amount in crustaceans during postharvest storage. Its levels were reported to be up to $400 \mathrm{mg} / \mathrm{kg}$ in Bombay-duck after cold storage [17, 18]. The formation of formaldehyde was more in Hilsha, Bombay duck, and Silver pomfret because of these are under the fatty fish group and also the higher microorganism's activity. More lipids present in muscles oxidize and produce more formaldehyde. [19]. Another explanation may be the fish that consume more zooplankton may have higher TMO in their muscle that produces higher formaldehyde [20,21].

Finally, after 20 hours the formaldehyde level was significantly decreased in all species where the Bombay-duck (12.1 mg/kg) and Sea bass $(5.2 \mathrm{mg} / \mathrm{kg})$ contained the highest and lowest amount of formaldehyde sequentially. Formaldehyde residue was influenced by the surface area of fish, storage temperature, post-harvest time, as well as the amount of dark muscle present in muscles. The fish which contains higher dark muscles comprise a higher amount of natural formaldehyde during post-harvest storage than the white one [22]. The opposite result was observed in some sea fishes because of microbial activity which influences the formation of formaldehyde [23]. 


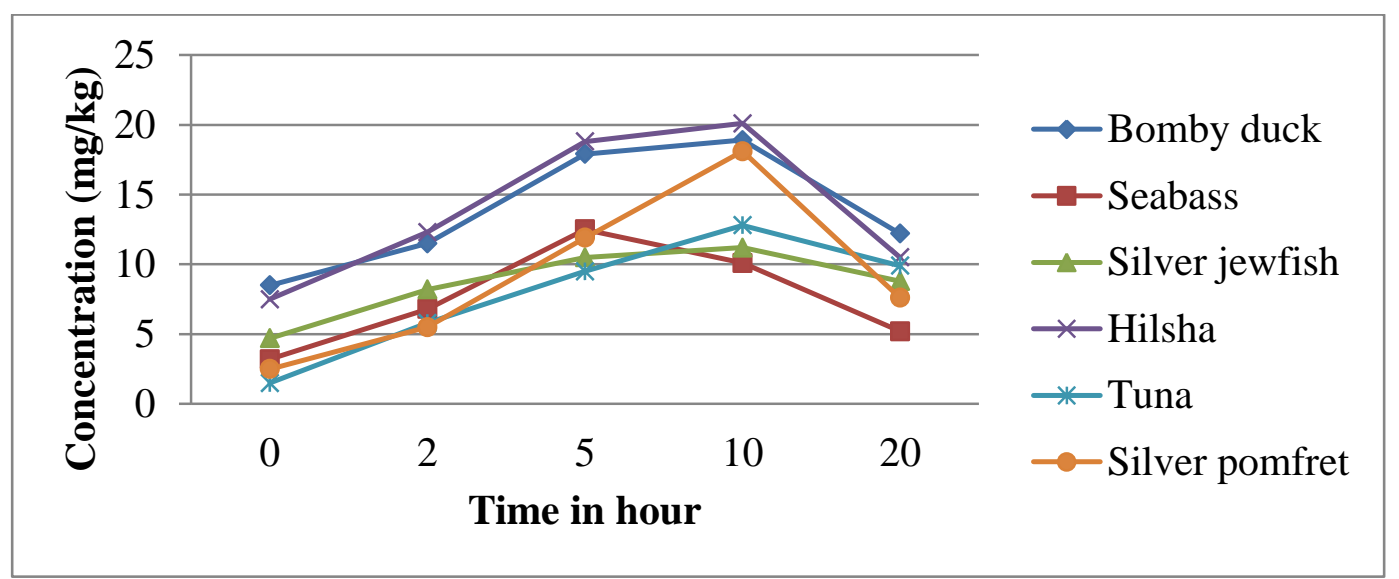

Figure 2: Changes in naturally occurring formaldehyde content with time of selected sea fish

\subsection{Changes in $\mathbf{p H}$ of the selected sea fish samples}

The $\mathrm{pH}$ values show an increasing trend in samples except for the Tuna muscle (0.03 units) and the highest increase in Silver Jewfish muscle by 0.82 units after 20 hours of room storage (Table 1). From the results, it is seen that there is a back-pedal relationship of $\mathrm{pH}$ with formaldehyde production in fish muscles. The fish which produce the lowest amount of formaldehyde during storage in ambient temperature have the highest value of $\mathrm{pH}$ and vice versa. The initial $\mathrm{pH}$ of muscles was lower (around 7.0), it may be due to the presence of glycogen in muscles which metabolized into lactic acid [24]. The pH value increases with time is attributed to the production of volatile basic compounds such as ammonia by fish spoilage bacteria and also due to the accumulation of alkaline compounds through autolytic activities and microbial metabolism has been described in earlier studies [25-27]. Conversely, many researchers agreed that the $\mathrm{pH}$ of the fish muscles showed a decreasing trend when stored in icestorage [28, 29].

Table 1: Changes in pH of the selected sea fish samples

\begin{tabular}{ccccccc}
\hline $\begin{array}{c}\text { Time } \\
(\mathbf{h r})\end{array}$ & Bomby duck & Seabass & Silver Jewfish & Hilsha & Tuna & SilverPomfret \\
\cline { 2 - 6 } 0 & $6.73 \pm 0.01^{\mathrm{a}}$ & $6.80 \pm 0.02^{\mathrm{a}}$ & $7.02 \pm 0.01^{\mathrm{a}}$ & $6.82 \pm 0.02^{\mathrm{a}}$ & $7.30 \pm 0.44^{\mathrm{a}}$ & $6.77 \pm 0.02^{\mathrm{a}}$ \\
2 & $6.80 \pm 0.01^{\mathrm{b}}$ & $6.82 \pm 0.01^{\mathrm{a}}$ & $7.03 \pm 0.02^{\mathrm{a}}$ & $6.92 \pm 0.02^{\mathrm{b}}$ & $7.00 \pm 0.05^{\mathrm{a}}$ & $6.82 \pm 0.02^{\mathrm{a}}$ \\
5 & $6.96 \pm 0.02^{\mathrm{c}}$ & $6.96 \pm 0.04^{\mathrm{ab}}$ & $7.14 \pm 0.02^{\mathrm{b}}$ & $7.01 \pm 0.04^{\mathrm{c}}$ & $7.09 \pm 0.01^{\mathrm{a}}$ & $6.97 \pm 0.01^{\mathrm{b}}$ \\
10 & $7.13 \pm 0.02^{\mathrm{d}}$ & $7.14 \pm 0.04^{\mathrm{b}}$ & $7.43 \pm 0.03^{\mathrm{c}}$ & $7.12 \pm 0.02^{\mathrm{d}}$ & $7.22 \pm 0.02^{\mathrm{a}}$ & $7.05 \pm 0.04^{\mathrm{c}}$ \\
20 & $7.23 \pm 0.01^{\mathrm{e}}$ & $7.39 \pm 0.19^{\mathrm{c}}$ & $7.84 \pm 0.08^{\mathrm{d}}$ & $7.50 \pm 0.05^{\mathrm{e}}$ & $7.33 \pm 0.02^{\mathrm{a}}$ & $7.27 \pm 0.02^{\mathrm{d}}$ \\
\hline
\end{tabular}

Values carrying different superscripts are significantly $(\mathrm{P}<0.05)$ different from each other when compare all pairs of columns. The results presented arethe means of three values followed by their standard deviation. $n=3$

\subsection{Microbial properties of selected sea fish samples}

The initial amount of total microbial load in sea fish samples of about 4.52-6.12 log $10 \mathrm{CFU} / \mathrm{g}$ (Table 2) indicates that the quality of sea fish had been good as it ranged from 2 to $6 \log 10 \mathrm{CFU} / \mathrm{g}$ [30]. This load varies from species to species depending on the place of catching, condition, and temperature of post-harvest operations of fishes [31]. In this study, the total bacterial load of fresh fish was found to be similar to those reported in the literature for fish stored aerobically and the count was lower than the value recommended by the International Commission of Microbiological Specification for Foods [32]. From the results, it was observed that amount of microbial load significantly increased in all samples with time crawling and was very high of about 15.76 and $14.41 \log 10 \mathrm{CFU} / \mathrm{g}$ in Silver jewfish and Sea bass respectively after 20 hours (Table 2).

The fish which produced a lower amount of formaldehyde in their muscle during storage had a higher microbial load with lapsing of time. This finding is alike to a study report where the initial total plate count of M. rosenbergii was $1.6 \times 102$ which was increased to $8.6 \times 107$ after exposed to ambient temperature for 8 hours [33]. Furthermore, another study also found volatile amine producing bacteria in sardine stored at an ambient temperature of $25-28^{\circ} \mathrm{C}$. This may be due to the fixative properties of 
formaldehyde by which it forms cross-bridges in protein and DNA molecules and toughening the muscles. Microorganisms are present on the external surface (including slime) and in the gut of fish. After death, they gradually invade the flesh while producing an ideal media for their growth and multiplication. As formaldehyde acts as a preservative, this why microbes invading into the fleshes was lower which produced higher formaldehyde during storage [34].

Table 2: Total microbial $\operatorname{load}(\log 10 \mathrm{CFU} / \mathrm{g})$ of the selected sea fish samples

\begin{tabular}{ccccccc}
\hline $\begin{array}{c}\text { Time } \\
(\mathbf{h r})\end{array}$ & Bomby duck & Seabass & Silver jewfish & Hilsha & Tuna & Silver pomfret \\
\cline { 2 - 6 } & $4.74 \pm 0.03^{\mathrm{a}}$ & $5.48 \pm 0.02^{\mathrm{a}}$ & $6.12 \pm 0.03^{\mathrm{a}}$ & $4.83 \pm 0.08^{\mathrm{a}}$ & $5.11 \pm 0.05^{\mathrm{a}}$ & $4.52 \pm 0.07^{\mathrm{a}}$ \\
2 & $4.81 \pm 0.03^{\mathrm{a}}$ & $5.87 \pm 0.03^{\mathrm{b}}$ & $6.18 \pm 0.08^{\mathrm{a}}$ & $5.24 \pm 0.05^{\mathrm{b}}$ & $5.79 \pm 0.05^{\mathrm{b}}$ & $4.86 \pm 0.04^{\mathrm{a}}$ \\
5 & $5.87 \pm 0.03^{\mathrm{b}}$ & $6.26 \pm 0.06^{\mathrm{c}}$ & $7.22 \pm 0.03^{\mathrm{b}}$ & $6.33 \pm 0.04^{\mathrm{c}}$ & $6.33 \pm 0.08^{\mathrm{c}}$ & $5.54 \pm 0.09^{\mathrm{b}}$ \\
10 & $6.79 \pm 0.04^{\mathrm{c}}$ & $8.12 \pm 0.12^{\mathrm{d}}$ & $8.85 \pm 0.05^{\mathrm{c}}$ & $7.69 \pm 0.05^{\mathrm{d}}$ & $6.93 \pm 0.05^{\mathrm{d}}$ & $7.73 \pm 0.25^{\mathrm{c}}$ \\
20 & $7.94 \pm 0.05^{\mathrm{d}}$ & $14.41 \pm 0.04^{\mathrm{e}}$ & $15.76 \pm 0.03^{\mathrm{d}}$ & $11.90 \pm 0.05^{\mathrm{e}}$ & $10.86 \pm 0.06^{\mathrm{e}}$ & $10.91 \pm 0.11^{\mathrm{d}}$ \\
\hline
\end{tabular}

Values carrying different superscripts are significantly $(\mathrm{P}<0.05)$ different from each other when compare all pairs of columns. The results presented are the means of three values followed by their standard deviation. $n=3$

\subsection{Shelf life of selected sea fish samples}

As the shelf-life of fish is more pointed than other foodstuffs that's why fishmongers have used adulterant to extend the mean life of fish. The shelf life of six marine fish species is given in Figure 3. The data obtained in this study indicate that the fish which produced a higher amount of formaldehyde in their muscles has a long time of edibility and vice versa. From Figure $\mathbf{3}$ it is seen that Silver pomfret and Bombay duck possessed a higher (about 8.5 hours) shelf-life while Sea bass and Silver jewfish were of near about 7.5 and 6.5 hours sequentially. The reason behind this, fish species which contains high pH, water activity, and TMAO accelerate the growth of microorganism the most determinants to settle the shelf-life of samples [35, 36]. Autolytic enzymatic breakdown may be another possible reason as it softens the fish muscles during post-harvest storage [37, 38]. Likewise, lipid oxidation could affect the edibility of fish by producing rancid odor as well as decrease the admissibility by customers [39, 40].

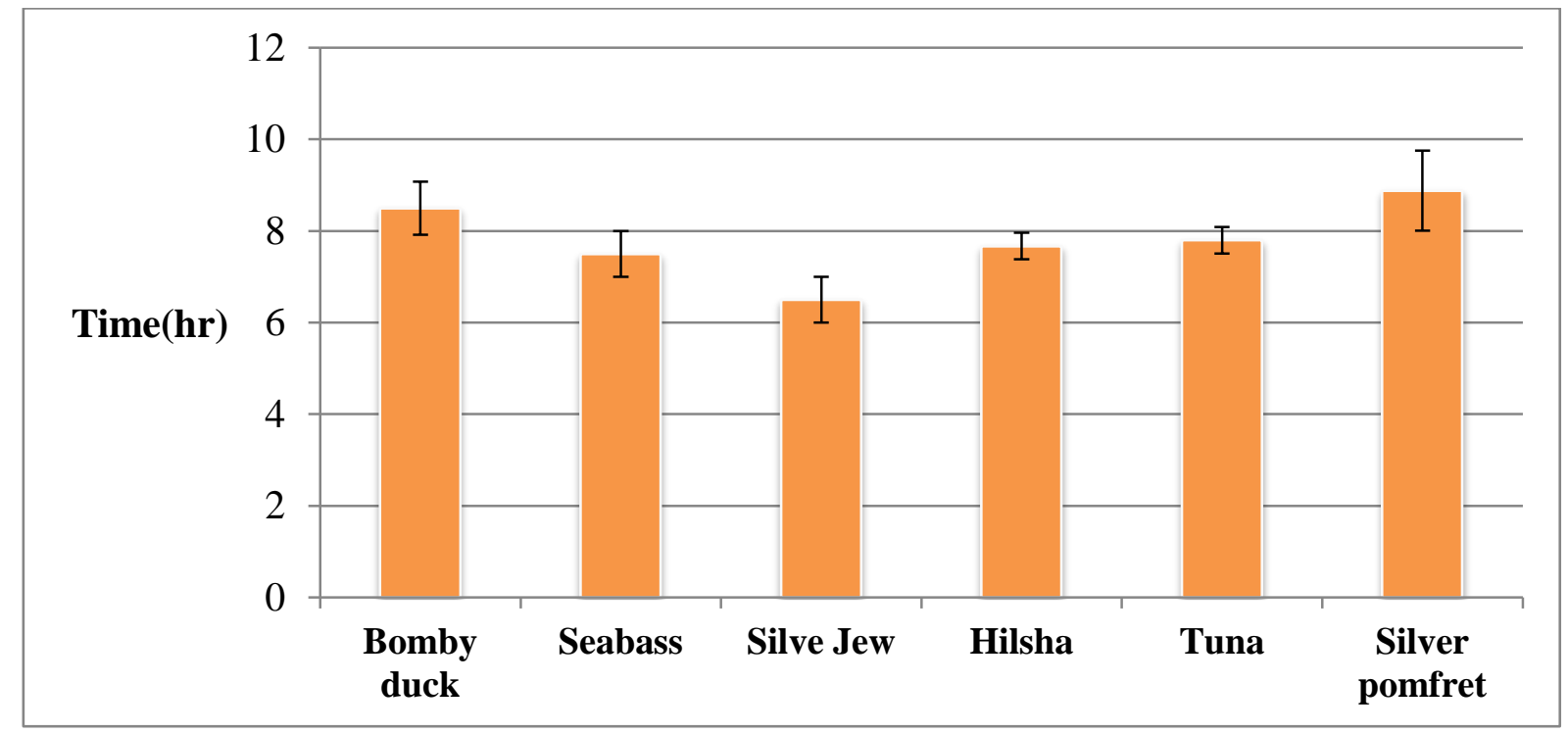

Figure 3: Shelf life of selected sea fish based on overall acceptability score

\section{CONCLUSION}

This study showed that a remarkable amount of natural formaldehyde produces in sea fish with time flies. However, the natural formaldehyde produced in fish samples influences longer shelf life while lower microbial load in muscle.

\section{ACKNOWLEDGEMENT}

The authors would like to express their gratitude and cordial thanks to the directorate of research and extension of Chattogram Veterinary and Animal Sciences University (CVASU), Bangladesh for the financial help supplies during the study period. The 
authors are greatly indebted to the director and the scientists associated with this research work of Poultry Research and Training Center (PRTC) and The Department of Applied Food Science and Nutrition, CVASU.

\section{REFERENCES}

1. Murray J, Burt JR. 2001. The composition of fish. Torry research station.FAO in partnership with support unit for International Fisheries and Aquatic Research, SIFAR.

2. Cunnane SC. 2010. Human brain evolution: a question of solving key nutritional and metabolic constraints on mammalian brain development. In Cunnane SC and Stewart KM (ed) Human brain evolution: the influence of freshwater and marine food resources. John Wiley \& Sons.

3. EthertonPMK, Harris WS, Appel LJ. 2002. Fish consumption, fish oil, omega-3 fatty acids, andcardiovasculardisease.Circulation106(21):2747-2757.DOI: 10.1161/01.CIR.0000038493.65177.94

4. FAO. 2018. The State of World Fisheries and Aquaculture 2018 - Meeting the sustainable development goals. Rome. Licence: CC BY-NC-SA 3.0 IGO.

5. DoF. 2018. Yearbook of Fisheries Statistics of Bangladesh, 2017-18. Fisheries Resources Survey System (FRSS), Department of Fisheries. Bangladesh : Ministry of Fisheries,2018. Volume 35 : p. 129.

6. Yeasmin T, Reza MS, Khan MNA, Shikha FH and Kamal M (2010) Present status of marketing of formalin treated fishes in domestic markets at Mymensingh district in Bangladesh. International Journal of Biological Research 1(4): 21 -24.

7. AngJF, Hultin HO. 1989. Denaturation of codmyosin during freezing after modification with formaldehyde. Journal of Food Science 54(4): $814-818$.

8. Badii F, Howell NK. 2002. Changes in the texture and structure of cod and haddock fillets during frozen storage. Food Hydrocolloids 16(4): 313 - 319.

9. PhillippyBQ, Hultin HO. 1993. Distribution and some characteristics of Trimethylamine-N-oxide (TMAO) demethylation of TMAO in minced red hake muscle. Journal of Food Biochemistry 17(4): 235- 255.

10. Kimura M, Seki N, Kimura I. 2003. Thermodynamic compensation of urea and trimethylamine N-oxide interactions with protein. Biophysical Journal 85(4): 108-125.

11. World Health Organization. 2002. Formaldehyde. Concise International Chemical Assessment, Document 40. Geneva: WHO

12. Li J, Zhu J, Ye L. 2007. Determination of formaldehyde in squid by high-performance liquid chromatography. Asia Pac J ClinNutr. ; 16(Suppl 1): 127-130.

13. Mehta NK, Shamasundar BA. 2015. Changes in chemical and sensory properties of fresh water Fish (Indian major craps) during ice storage. Prog. Agric. 15 (2): 202-207. Society for Recent Development in Agriculture. DOI : 10.5958/09764615.2015.00007.1

14. Collins CH, Lyne PM. 1976. Understanding of microbiologically influenced corrosion. In Grange, J.M. and Falkinham, J.O. (Eds.). Microbiological Methods. 4th ed., p. 450.

15.Uddin MM, Amit SK, Islam SMR, Rahman R, Sameera S, Khan MS. 2014. Analyzing Time Dynamic Concentration of Formaldehyde in Fresh and Formalin Treated Fish 'Labeorohita', International Conference on Chemical Engineering ICChE : 29-30.

16. Sotelo CG, Pineiro C, Perez-Martin RI. 1995. Denaturation of fish proteins during frozen storage, role of formaldehyde Zeitschrift fur LebensmittelUntersuchung under-Forschung 200 14-23.

17. Anderson DWJr, Fellers CR. 1952. The occurrence of trimethylamine and trimethylamine oxide in fresh water fishes. Food Res.17, 472-474.

18. Hebard CE, Flick GJ, Martin RE. 1982. Occurrence and significance of trimethylamine oxide and its derivatives in fish and shellfish. In Chemistry and Biochemistry of Marine Food Products (ed. R. E. Martin, G. J. Flick, C. E. Hebard and D. R. Ward), pp. 149-304. Westport, CT: AVI Publishing Company.

19. Cui, X., Fang, G., Jiang, L. and Wang, W. 2007. Kinetic spectrophotometric method for rapid determination of trace formaldehyde in foods. AnalyticaChimicaActa 590(2): 253-259.

20. Stroem AR, Olafsen JA, Larsen H. 1979. Trimethylamine oxide: a terminal electron acceptor in anaerobic respiration of bacteria. J. Gen. Microbiol., 112, 315-20.

21.Belinske, E. (1964). Biosynthesis of trimethylammonium compounds in aquatic animals. Precursors of trimethylamine oxide and betaine in marine teleosts. J. Fish. Res. Board Can., 21, 765-771.

22.Jaafar RM, Kuhn JA, ChettriJK, Buchmann K. 2013. Comparative efficacies of sodium percarbonate, peracetic acid, and formaldehyde for control of Ichthyobodonecator- an ectoparasitic flagellate from rainbow trout. ActaIchthyologicaEtPiscatoria 43(2): 139-143.

23. Bianchi F, Careri M, Musci M, Mangia A. 2007. Fish and food safety: determination of formaldehyde in 12 fish species by SPME extraction and GCMS analysis. Food Chemistry 100(3): 1049-1053.

24. Kyrana VR, Lougovious VP, Valsamis DS. 1997. Assessment of shelf-life of maricultured gilthead sea bream (Sparusaurata) stored in ice. International Journal of Food Science and Technology 32(4): 339- 347.

25.Lalitha KV, Sonaji ER, Manju S, Jose L, Gopal TK. 2005. Microbiological and biochemical changes in pearl spot (Etroplussuratensis Bloch) stored under modified atmospheres. Journal of Applied Microbiology 99: 1222-1228.

26. Ruiz-Capillas C, Moral A. 2001. Correlation between biochemical and sensory quality indices in hake stored in ice. Food Research International Journal 34: 441-447. 
27. Pons-Sanchez-Cascado S, Veciana-Nogues MT, Bover-Cid S, Marine-Font A, Vidal-Carou MC. 2006. Use of volatile and non-volatile amines to evaluate the freshness of anchovies stored in ice. Journal of the Science of Food and Agriculture 86: 699-705.

28. Hossain MI, Islam MS, Shikha FH, Kamal and Islam, MI. 2005. Physicochemical changes in Thai Pungus (Pungasiussutchi) muscle during ice storage in storage in an insulated box. Pakistan Journal of Biological Science, 8(6): 798-804.

29. Fan, Wenjiao, Chi Y, Zhang S. 2008. The use of tea polypheol; dip to extend the shelf life of silver carp (Hypophthalmicthys molitrix) during ice storage. Food Chemistry, 108: 148-153.

30. Huss HH. 1995. Quality and Quality changes in fresh fish. Fisheries Technical Paper, FAO, Rome pp: 348.

31.Perigreen PA, Jose Joseph, SurendranPK and Gopakumar K, 1987. Studies on iced storage of common murrel (Channastriatus). Fishery Technology, 24 : 99-102.

32.ISO, 2004a. Microbiology of food and animals feeding stuffs-Horizontal methods for sampling techniques from surfaces using contact plates and swabs. ISO Norm 18593: 2004. International Standardization Organization ed., Geneva Switzerland.

33. Premaratne RJ, Nip WK, Moy JH. 1986. Characterization of proteolytic and collagenolyticpsychrotrophic bacteria of ice stored freshwater prawn, Macrobrachiumrosenbergii. Marine Fisheries Review 48(2):44-47

34. Ababouch L, Afilal ME, Benabdeljelil H, Busta FF. 2007. Quantitative changes in bacteria, amino acids and biogenic amines in sardine (Sardinapilchardus) stored at ambient temperature $\left(25-28^{\circ} \mathrm{C}\right)$ and in ice. International Journal of Food Science and Technology 26 (3): 297-306.

35. Chaillou S, Chaulot-Talmon A, Caekebeke H, Cardinal M, Christieans S, Denis C, Desmonts MH, Dousset X, Feurer C, Hamon E. 2015. Origin and ecological selection of core and food-specific bacterial communities associated with meat and seafood spoilage. ISME J;9:1105-1118. doi: 10.1038/ismej.2014.202.

36. Hassoun A, Çoban OE. 2017. Essential oils for antimicrobial and antioxidant applications in fish and other seafood products. Trends Food Sci. Technol.;68:26-36. doi: 10.1016/j.tifs.2017.07.016

37.Lyhs U, Lahtinen J, Schelvissmit R. 2007. Microbiological quality of maatjes herring stored in air and under modified atmosphere at 4 and $10^{\circ} \mathrm{C}$. Food Microbiol;24:508-516. doi: 10.1016/j.fm.2006.08.003.

38. OcañohigueraVM, Maedamartínez AN, Marquezríos E, Canizalesrodríguez DF, Castilloyáñez FJ, Ruízbustos E, Gracianoverdugo AZ, Plascenciajatomea M. 2011. Freshness assessment of ray fish stored in ice by biochemical, chemical and physical methods. Food Chem; 125:49-54. doi: 10.1016/j.foodchem.2010.08.034.

39.Losada V, Barros-Velázquez J, Aubourg SP. 2007. Rancidity development in frozen pelagic fish: Influence of slurry ice as preliminary chilling treatment. LWT-Food Sci. Technol; 40:991-999. doi: 10.1016/j.lwt.2006.05.011.

40. Beck C. 2014. Effects of high pressure processing on lipid oxidation: A review. Innov. Food Sci. Emerg. Technol; 22:1-10. 